\title{
Academic Journal Ranking: Important to Strategic Management and General Management Researchers?
}

\author{
Robert P. Yuyuenyongwatana \\ Cameron University • Lawton, OK \\ Shawn M. Carraher \\ Cameron University • Lawton, OK
}

\section{Abstract}

This study explores two questions pertaining to research publications: the importance of publications, and the perceived ranking of strategic and general management journals. The reasons why research publishing is important are 1) it is part of the pursuit of knowledge, 2) it has extrinsic rewards to those publishing, and 3) it may increase the prestige of the institution with which the publishing faculty is affiliated. On the second question, the authors have conducted a survey of perceived journal rankings. The results from 50 journals suggest that there is a consensus of rankings. As such, an institution may reasonably use these rankings as a basis for evaluations of research quality. Areas for future research are suggested.

\section{Introduction}

The academic world places strong emphasis in research and subsequent publications of their findings. The field of management is no exception. Why are research publications important? How important is the concept of journal ranking publishing academicians? This paper attempts to answer these two questions for strategic management and general management subspecialties.

Research is important to academic pursuit. Demski and Zimmerman (2000) suggested five reasons for research activities. First, research leads to "compression" of observed phenomenon into compact ideas, in order to better understand the world, and still retain key information. Second, research creates "intensive social process," (p. 345) for it encourages debates of ideas, critiques each other's work, and other social interactions necessary in academic processes. Third, academicians produce relatively few significant publications resulting in concentrated published works by a few notable authors. Finally, research makes better teaching. It forces critical thinking. Professors who do research and publish are often thought of as offering high standards in teaching and, therefore, may be better teachers.'

Publication productivity is often used as part of tenure, promotion, and faculty merit pay considerations. Park and Gordon (1996) found that in the field of 
strategic management, that at institutions with graduate programs in management, the average publication rate of faculty who received tenure was five journal articles, while the average publication record of those not receiving tenure was two journal articles. ${ }^{2}$ Gomez-Mejia and Balkin (1992) surveyed a sample of 352 management professors and found the most significant determinant of faculty pay levels at both doctorate and non-doctorate degree granting institutions was publications in toptier journals.

As for merit awards, Manning and Barrette (2005) report that the School of Business at the University of Ottawa, Canada, created a system in order to classify management journals in to $\mathrm{A}, \mathrm{B}$, and $\mathrm{C}$ categories (i.e., A-level journals being the highest, most prestigious, category) based upon the citation rates of articles published in the journals. Faculty who published in A, B, and C-level journals would receive $C \$ 8,000, C \$ 6,000$, and $C \$ 3,000$, respectively. The university also included "NotABC" and Practitioner categories for journals which were not eligible for the reward program. Vikas, Lawrence, and Murshed (2008) used a sample of 298 marketing professors from 33 research-oriented public universities and found research productivity to have a positive impact on average annual salary among marketing faculty, confirming similar findings in other disciplines. Specifically, they found that publication in a Tier 1 Marketing journal would add $\$ 2,176.25$ to one's average annual salary, while publishing in a Tier 2 journal would add $\$ 1,777.95$ to one's average annual salary, and publishing a Tier 3 journal would add $\$ 124.85$. This compares well to the previously mentioned study by Gomez-Mejia and Balkin (1992) where they found that in management a top tier publication would add $\$ 1,210$ to one's average annual salary [in 1988 dollars] while publications in other journals did not increase average faculty salaries.

Research publications may also bring prestige and status to an institution (Manning \& Barrette, 2005). Reputable institutions, especially research oriented ones, often require that their faculty publish in top-tier journals. The publishing requirements further foster and enhance the prestige of these universities (Kirkpatrick \& Locke, 1992). For instance, Fogarty and Ravencroft (1999) examined a population of accounting PhDs between 1986 and 1996. They found a strong relationship between the willingness of faculty to publish and the status of an institution. Siemens, Burton, Jensen, and Mendoza (2005) examined the relationship between top-tier business journals and university rankings conducted by U.S. News \& World Report between 1986 and 1998. They found that research productivity was significantly related to program rankings for the undergraduate business school by the U.S. News \& World Report. Additionally, Long, Bowers, Barnett, and White (1998) found a 
strong relationship between research productivity [as measured by the number of publications in top-tier journals and citation counts] and institutional status. In order to increase the status of a university it is imperative that faculty publish more in top quality journals (Long, et al., 1998; Manning \& Barrette, 2005).

The above reasons make a strong case for the importance of publications. Many benefits accrue to publishing in top-tier journals including promotions, tenure, possible merit raises, and increased organizational status. Due to these issues many institutions engage in identifying and ranking journals in the business disciplines (Chrisman, Chua, Kellermanns, Matherne, \& Debicki, 2008; Katz, 2003, 2008; Kuratko, 2005; Manning \& Barrette, 2005). Therefore, in the current study, we examine the ranking of general management journals by faculty members from a wide spectrum of American universities.

\section{Methodology}

The data used in this analysis was collected from a survey in which each participant was asked to rank each of 50 management journals using a Likert-like scale from 1 (not top tier) to 9 (top tier). The data was collected at three management related conferences in 2008: the Academy of Management, Small Business

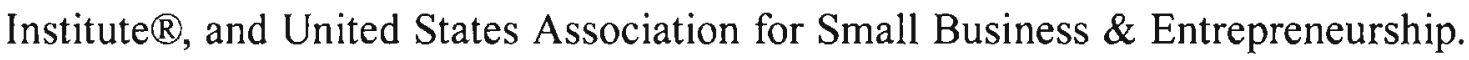
Of 700 conference participants sampled, 250 responses are deemed useful to be included in the study. All respondents are subjected to strict anonymity. On average $78 \%$ of the respondents were male, 55.8\% were Professors, was 55 years of age, had been teaching for 22.7 years and had 26.25 journal and .69 book publications.

This study selected and ranked 50 journals that are closely related to strategic and general management. A mean rating scale was calculated for each journal utilizing a 9-point scale ranging from "top tier" (9) to "not top tier" (1). Using this mean rating scale, the journals are then ranked with number one with the highest mean rating scale to number fifty with the lowest mean. The study also includes quartile calculation as an alternate way of looking at a journal standing in relation to group ranking (for example, bottom $25 \%$, median, and top $25 \%$ ).

\section{Results and Discussions}

Table 1 shows the results of the survey. It reports listing of the 50 journals, their rankings, means, and standard deviations. Table 2 shows quartiles of the means. For example, the results of the survey indicate a 12th ranking for the Journal of Business Strategies (JBS). Table 2 shows that JBS is in the top quartile of journals 


\section{Table 1}

\section{Journal Ranking of 50 Management Journals}

\section{Journal Title}

Academy of Management Journal

Journal of Applied Psychology

Academy of Management Review

Strategic Management Journal

Management Science

Journal of International Business Studies

Journal of Management

Administrative Science Quarterly

Organization Science

International Journal of Family Business

Case Research Journal

Journal of Business Strategies

AOM Learning \& Education

Journal of Management History

AOM Perspectives

Journal of Management Studies

Public Administration Quarterly

California Management Review

International Journal of Sustainable

Strategic Management

Personnel Review

Journal of International Entrepreneurship

International Journal of Production Research

International Journal of Information Technology and Management

Journal of International Business and Entrepreneurship

Journal of Technology Management in China

Organizational Dynamics

Management Decision

International Journal of Technological Innovation and Entrepreneurship

Baltic Journal of Management

International Journal of Entrepreneurship

Journal of Managerial Issues

Journal of Strategic Information Systems
Ranking Mean Std. Dev. Quartile

$\begin{array}{cccc}1 & 8.75 & .672 & 1 \\ 2 & 8.69 & .799 & 1 \\ 3 & 8.60 & .891 & 1 \\ 4 & 8.22 & .980 & 1 \\ 5 & 7.91 & .774 & 1 \\ 6 & 7.73 & 1.448 & 1 \\ 7 & 7.13 & .838 & 1 \\ 8 & 6.84 & 2.373 & 1 \\ 9 & 6.23 & 1.524 & 1 \\ 10 & 5.79 & 2.323 & 1 \\ 11 & 5.76 & 1.453 & 1 \\ 12 & 5.67 & 2.001 & 1 \\ 13 & 5.61 & 1.623 & 1 \\ 14 & 5.57 & 2.553 & 2 \\ 15 & 5.46 & 1.394 & 2 \\ 16 & 5.33 & 1.311 & 2 \\ 17 & 5.22 & 1.983 & 2 \\ 18 & 5.22 & 2.289 & 2 \\ 19 & 5.15 & 1.447 & 2\end{array}$

$\begin{array}{lll}5.15 & 1.969 \quad 2\end{array}$

$\begin{array}{lll}4.92 & 1.872 \quad 2\end{array}$

$\begin{array}{lll}4.92 & 1.757 \quad 2\end{array}$

$\begin{array}{lll}4.87 & 1.269 \quad 2\end{array}$

25

26

27

28

$\begin{array}{lll}4.85 & 1.968 \quad 2\end{array}$

$4.60 \quad 1.376 \quad 3$


Organization Studies

Cornell Hotel and Restaurant Administration

Quarterly

Journal of International Business

35

$4.15 \quad 1.196 \quad 3$

and Enterprise Development

Personnel

Business Horizons

International Journal of Entrepreneurship

Development, Education \& Training

Journal of Asia Entrepreneurship and Sustainability 39

$\begin{array}{lll}3.76 & 1.212 \quad 4\end{array}$

Management Studies

40

$3.61 \quad 1.286 \quad 4$

Planning Review

3.59

2.0734

Long Range Planning

Entrepreneurship Advancement, Strategy,

\& Education

Small Business and Enterprise Development

Journal of Enterprising Culture

$\begin{array}{llll}44 & 3.47 & 1.243 & 4 \\ 45 & 3.38 & 1.712 & 4 \\ 46 & 3.27 & 1.242 & 4 \\ 47 & 3.16 & 1.544 & 4\end{array}$

Asian Journal of Business \& Entrepreneurship

47

3.16 and Management

Public Personnel Management

Business Journal for Entrepreneurs Quarterly

48

3.07

$.848 \quad 4$

Central Business Journal

49

2.76

.8934

50

2.63

1.186

\section{Table 2}

\section{Quartiles of the Mean Ratings}

$\begin{array}{ll}\text { Maximum } & 8.75 \\ \text { Quartile 75\% (top 13 journals) } & 5.61 \\ \text { Quartile 50\% (Median) } & 4.66 \\ \text { Quartile 25\% (bottom 12 journals) } & 3.87 \\ \text { Minimum } & 2.63\end{array}$

- an appropriate ranking in consideration of its 25 years of publishing quality research articles. Of the 50 journals evaluated in this analysis the respondents ranked the Academy of Management Journal as the number one journal (mean of 8.75 and standard deviation of 0.67 ). For the fifty journals the standard deviations ranged from 0.67 to 2.55 with an average standard deviation being 1.56 . The rankings of the fifty journals show very little deviation, implying that there is more of a consensus of the rankings among the respondents. 


\section{Conclusions}

This study explores the two questions pertaining to research publications: the importance of publications and the perceived ranking of strategic and general management journals. The reasons why research publishing is important include 1) it is an important part of the pursuit of knowledge, 2) it has extrinsic rewards to those who are publishing [they typically earn more money], and 3) it increases the status and prestige of the institution with which the authors are affiliated.

On the second question, the authors have conducted a survey of perceived journal rankings. The results of these 50 journals suggest that there is a consensus of rankings. As such, an institution may reasonably use these rankings as a basis for evaluations of research quality in management.

Future researchers could expand the sample size of respondents and journals in order to fully represent the spectrum of publishing outlets for business researchers (Sturman \& Carraher, 2007). Greater numbers of journals in all areas of management should be included, as well as journals from other areas of business. As JBS also publishes articles in other disciplines within business, we believe that the current findings likely underestimate the ranking of the journal across the business disciplines.

Finally, a survey should include questions that would explore reasons as to why a respondent would rank a particular journal at the level that they would rank it, how important the rankings are to him or her, and also seek to examine if prior publication experiences with journals have influenced respondents' impressions of the journals. We congratulate JBS on the publication of the 50th issue and look forward to the journal's continued rise in the future.

\section{End Notes}

1. Tanner and Manakyan (1992) found no significant link between teaching performance and research activity. The two variables are independent of one another.

2. They also found that institutions without graduate program tended to consider service and teaching to be more important to a decision to grant tenure.

\section{References}

Chrisman, J. J., Chua, J. H., Kellermanns, F. W., Matherne III, C. F., \& Debicki, B. J. (2008). Management journals as venues for publication of family business research. Entrepreneurship Theory and Practice, 32(5), 927-934. 
Davis, J. C., Huston, J. H., \& Patterson, D. M. (2001). The scholarly output of economists: A description of publishing patterns. American Economic Journal, 29(3), 341-349.

Demski, J. S., \& Zimmerman, J. L. (2000). On "research vs. teaching": A long-term perspective. Accounting Horizons, 14(3), 343-352.

Fogarty, T .J., \& Ravencroft, S. P. (1999). The importance of being "wordy": Willingness to write and publication productivity among accounting academics. $A c$ counting Education, 8(3), 187-202.

Gomez-Mejia, L. R., \& Balkin, D. B. (1992). Determinants of faculty pay: An agency theory perspective. Academy of Management Journal, 35(5), 921-955.

Katz, J. (2003). The chronology and intellectual trajectory of American entrepreneurship education 1876-1999. Journal of Business Venturing, 18, 283-300.

Katz, J. (2008). Fully mature but not fully legitimate: A different perspective on the state of entrepreneurship education. Journal of Small Business Management, 46(4), 550-566.

Kirkpatrick, S. A., \& Locke, E. A. (1992). The development of measures of faculty scholarship. Group and Organization Management, 17, 5-23.

Kuratko, D. F. (2005). The emergence of entrepreneurship education: Development, trends, and challenges. Entrepreneurship Theory \& Practice, 29(5), 577-597.

Long, R. G., Bowers, W. P., Barnett, T., \& White, M. C. (1998). Research productivity of graduates in management: Effects of academic origin and academic affiliation. Academy of Management Journal, 41(6), 704-714.

Manning, L. M., \& Barrette, J. (2005). Research performance management in academe. Canadian Journal of Administrative Sciences, 22(4), 273-287.

Park, S. H., \& Gordon, M. E. (1996). Publication records and tenure decisions in the field of strategic management. Strategic Management Journal, 17(2), 109-128.

Siemens, J. C., Burton, S., Jensen, T., \& Mendoza, N. A. (2005). An examination of the relationship between research productivity in prestigious business journals and popular business school rankings. Journal of Business Research, 58(4), 467-476.

Sturman, M., \& Carraher, S. (2007). Using a random-effects model to test differing conceptualizations of multidimensional constructs. Organizational Research Methods, 10(1), 108-135.

Tanner, J. R., \& Manakyan, H. (1992). Management-faculty research productivity and perceived teaching effectiveness. Journal of Education for Business, 67(5), 261-265.

Vikas, M., Feick, L., \& Murshed, F. (2008). Publish and prosper: The financial impact of publishing by marketing faculty. Marketing Science, 27(3), 430-442. 


\section{Biographical Sketches of Authors}

Robert Yuyungyongwatana received his Ph.D. in Finance from North Texas State University. He is Professor of Finance at Cameron University. His recent publications have appeared in the International Journal of Family Business, Global Finance Journal, Journal of Derivatives, and the Midwestern Business and Economic Review.

Shawn M. Carraher received his Ph.D. in Business Administration from the University of Oklahoma. He is the Virginia Brewczynski Endowed Chair and Director of the Small Business Institute ${ }^{\circledR}$ at Cameron University. He has published over 100 journal articles and his most recent publications having appeared in the Journal of Applied Psychology, Organizational Research Methods, Journal of International Business Studies, Journal of Applied Management and Entrepreneurship, and the Journal of Business Strategies. His research focuses on a variety of international entrepreneurship topics in the health care and tourism industries. 